IJHS, e-ISSN 2597-4718, p-ISSN 2597-470X, Vol. 2, No. 2, March 2019, pp. 114-122

International Journal of Humanity Studies

IJHS

International Journal of Humanity Studies

http://e-journal.usd.ac.id/index.php/IJHS

Sanata Dharma University, Yogyakarta, Indonesia

\title{
NOVEL AND REFIGURING LIFE
}

\author{
F. Wawan Setyadi \\ Centre Sèvres, Paris \\ wawan.setyadi@gmail.com \\ DOI: https://doi.org/10.24071/ijhs.2019.020201
}

received 18 December 2018; revised 20 January 2019; accepted 20 February 2019

\begin{abstract}
This article explores the confluence between a novel and the life of its reader in two phases. Firstly, this article examines the theory of mimesis of Paul Ricœur in Time and Narrative I to arrive at the importance of the reading act where the reader does his own appropriation of the novel read. The novel itself is a creative composition based on the daily human actions. Secondly, this article deciphers the work of Milan Kundera, especially his concept of existential code, found in the novel The Unbearable Lightness of Being and sharpened by his concept of writing novels in The Art of the Novel. This second phase gives another articulation of the first phase, which is more philosophically theoretical. Based on these two phases of exploration, this article uncovers the refigured man who comes to understand both himself and the world he lives in better and who has new different propositions and possibilities to live better as well.
\end{abstract}

Keywords: mimesis, prefiguration, configuration, refiguration, existential code

\section{Introduction}

Why do people write novels and why do we continue to read them? These are the main questions of this essay. Behind these questions, there is a subtler problematic concern about the relation between novel or arts in general and life itself. Is novel enclosed in itself, for its own sake, and therefore it has nothing to do with life of its readers? Or, does it go beyond itself and points out the life of its readers? To help our reflection, firstly, we will examine the mimesis theory by Paul Ricœur (1913-2005), a French philosopher known for his work on philosophical hermeneutic. His mimesis theory which is placed in milieu of his hermeneutic of text will serve as theoretical or philosophical foundation for this article. Afterward, it is important to listen to the novelist himself. Milan Kundera will illumine us when he explains about the existential codes of the characters in his novels. This will be the second section of this essay. The encounter between Ricœur and Kundera will be the backbone of the essay which will give us sufficient understanding about the relation between novels and life.

Understanding of texts and life by means of mimesis theory or the narrativity theory by Ricœur is helpful in, in this case, literature analysis. The wealth of 
literature studies has made use of Ricœur's theory. Young (2014), for instance, owes to Ricœur in reading James Joyce's short story "Evelyne" and Tóibín's novel Brooklyn (2014). The theory is also useful in fiction studies as done systematically by Ferguson (2014). Novel and refiguration of life becomes an important concept from the Ricœurian hermeneutical philosophy, that is, the concept of narrative identity. The discussion that follows therefore will examine the structure of Ricœur's narrativity.

\section{The Threefold Mimesis}

In his trilogy concerning human time and narrative theory, Temps et Récit, Paul Ricœur develops his mimesis theory. It is found in the third chapter of the first volume, right after his analysis of time, based on the book XI of Confessiones of Augustin, in the first chapter and the analysis of muthos (emplotment), based on the Poetics by Aristotle, in the second chapter. Later, in his intellectual autobiography, Réflexion faite, Ricœur affirms that the intersection between these two books is the foundation of his theory in this trilogy. While the analysis of Augustinian time does not include the narrative theory, the Aristotelian analysis of the muthos tragic does not speak in particularly about time. Indeed, the analysis of time in this trilogy extends to the reflection concerning time from Aristotle, Husserl, and Heidegger alongside the critique that Ricœur gives to them as comprehensively discussed by, for example, Tengelyi (2011) and Dastur (2011). This article however limits itself in discussing the originality of this trilogy whereby Ricœur develops mediation between time and narrativity.

To understand the mediation between time and narrative, it is important to look at Ricœur's trilogy that he states briefly as follows, "time becomes human time to the extent that it is organized after the manner of a narrative; narrative, in turn, is meaningful to the extent that it portrays the features of temporal experience." (Ricœur, 1984, p. 3, 52). This single theme will serve as leitmotiv of this trilogy and thus will permeate the very vast studies in these three volumes. Since the theory of threefold mimesis lays in the core of the mediation of these two independent analyses: time and muthos tragic, the point of gravity of the mediation between time and narrative moves, thus, to the dynamic between these three mimesis, which calls mimesis 1, mimesis $_{2}$, and mimesis 3 . In this threefold mimesis, Ricœur himself states that mimesis 2 functions as the pivot of the other two mimesis. What follows is elaboration of each mimesis.

To begin with, what is mimesis according to Ricœur? It is a creative imitation; a mimetic activity of human action in three phases (cf. Ricœur, 1984, p.31ss). It is creative since this imitation has a new form in the narrative composition. In this sense, it is a new creation, thanks to the new semantic innovation in the employment. In the preface of the Time and Narrative $I$ he has this to say: "Plot, says Aristotle, is the mimesis of an action. When the time comes, I shall distinguish at least three senses of this term mimesis: a reference back to the familiar pre-understanding we have of the order of action; an entry into the realm of poetic composition; and finally a new configuration by means of this poetic refiguring of the pre-understood order of action." (Ricœur, 1984, p. xi). In other words, this mimetic activity of human action for Ricœur consists in three 
phases: pre-figuration in mimesis ${ }_{1}$, con-figuration in mimesis ${ }_{2}$, and re-figuration in mimesis 3 . To understand better, elaboration of each is important herein.

\section{Mimesis 1}

In this prefiguration phase, Ricœur, attempts to show that the daily human activities have already a narrative structure and that this world of action is the departure points of the composition narrative in the next phase of mimesis. In his elaboration, Ricœur mentions three characteristics of the world of action: its meaningful structure, its symbolic resources, and its temporal character. By its meaningful structure, Ricœur elucidates the semantic of human actions. Briefly, in this semantic, human actions always contain goals, motif, and agent. To these three factors, he adds that human actions are always an action with others, which can take form as cooperation or competition. In the end, these actions will terminate in change of fortune, either toward happiness or toward misfortune. (Ricœur, 1984, p. 55ss)

The symbolic mediation as the second features of mimesis 1 serves, firstly, as a sign that make an action readable. A symbol of waving hand, for example, makes the action of saying goodbye understood. Secondly, it serves as a kind of rule to interpret an action. By symbolic mediation as a rule of interpretation, a waving hand is understood as a gesture of saying goodbye. Thirdly, the symbolic mediation serves as a norm of conduct. If someone wants to say goodbye politely, then he can wave his hand (Ricœur, 1984, p. 57ss). After elaborating this symbolic mediation, Ricœur elucidates the temporal character of human actions, approaching himself to the Heidegerian concept of within-time-ness (Innerzeitigkeit). One important thing to underline in this part is that time means time to do something. It is not just the linear time which passes, but time existential in which whenever someone says "now..." it means "right now that (I do...)" (Ricœur, 1984, p. 59ss).

\section{Mimesis2}

This is the configuration phase, where the emplotment takes place. Based on what is received from the mimesis ${ }_{1}$, it is time now to arrange the new semantic innovation. The heterogeneity of temporal human actions is synthetized and transformed in a new plot. The human experiences become a new text or a new composition, thanks to this plot creative. In this phase, we find the meaning of mimesis in its strict sense. Nonetheless, this configuration phase, as the pivot of the threefold mimesis, does not only mediate the human experiences in the mimesis, but it also prepares what Ricœur, explains in the next phase of the mimesis (Ricœur, 1984, p. 64ss).

\section{Mimesis $_{3}$}

This refiguration phase is activated in the act of reading. Thus, it will not be possible without the composition narrative which takes place in the configuration phase of mimesis2. What is important here is that the act of reading will decipher different propositions from the text read. Ricœur specifically underlines here that what a narrative composition proposes is a new possibility to live better in the world. In other words, this narrative composition refers to a second degree of reality or a new hypothetic world, where there are possibilities to live better. In fact, in The Rule of Metaphor published in 1975, Ricœur earlier on mentions this referential status of the text in his study of metaphor. The metaphor is not enclosed in himself; it is not made for his own sake, but it bursts out to refer to a 
world, to a new reality, thanks to the new semantic pertinence (Ricœur, 1984, p. $\mathrm{x}$-xi).

This proposition can only be activated and actualized by the act of reading. The world of the text and the world of the readers will interact in this phase. By this act of reading, the narrative composition will be complete since the reader will complete the lacuna, the indetermination in the text he read by his appropriation. By doing so, the text will be his and will have impact to his personal life. This act of reading will end in the application of what has been read and appropriated in the concrete action in life. The narrative composition sends the reader back to his daily, but this time, being different from the world action in the mimesis 1 , he will appear in a new way, thanks to appropriation that leads into refiguration (Ricœur, 1984, p. 76ss).

It is also important to note that this act of reading is what Ricœur did not elaborate when working on The Rule of Metaphor. By the time he wrote the vast study of metaphor, he underlined only the referential status of metaphor, what in this present work is called as the reality of second degree or the hypothetic world. The act of reading was just supposed. It is only around ten years after, in the Time and Narrative, which he arrives to elucidate this act of reading as the ultimate vector of mimesis (Ricœur, 1984, p. 77ss).

Thus, to resume, the temporal experience of human being is worked in this narrative functions, as Ricœur himself states, "We are following therefore the destiny of a prefigured time that becomes a refigured time through the mediation of a configured time." (Ricœur, 1984, p. 54). The moment of reading becomes a precious moment. At this particular time, the current of our temporal experiences in the daily life is suspended for being recharged by the novel we read, as also claimed by Prammer (2013) about the fruitful experience of reading. In his book, Jean Grondin (2013, p.103 [my translation]) puts this threefold mimesis in a schema of narrative arc that may help our understanding.

Table 1. Narrative Arc

\begin{tabular}{lll}
\hline Mimèsis I & $\leftarrow$ Mimèsis II $\rightarrow$ & \multicolumn{1}{c}{ Mimèsis III } \\
\hline Prefiguration narrative & Configuration narrative & Refiguration narrative \\
$\begin{array}{l}\text { Understanding of the already } \\
\text { narrative life and temporal } \\
\text { experience }\end{array}$ & $\begin{array}{l}\text { Emplotment narrative in a } \\
\text { muthos creative }\end{array}$ & $\begin{array}{l}\text { Appropriation of the plot by } \\
\text { the reader and the } \\
\text { application of this plot in his } \\
\text { existence }\end{array}$ \\
\hline
\end{tabular}

\section{Method}

This qualitative descriptive study examines a novel, Time and Narrative I, The Unbearable Lightness, and The Art of the Novel from the theory of mimesis by Paul Ricœur. After collecting the data, narrativity theory by Ricœur is used in examining the texts in the novel. The interpretations of the data are seen in the Ricœurian hermeneutical philosophy, that is, the concept of narrative identity. The structure of Ricœur's narrativity will further be investigated. 


\section{Findings and Discussion}

\section{The Novel and the Existential Code}

Having explored the theory of threefold mimesis that depicts life, the discussion now turns to the side of the novelist. For this purpose, we shall see how Milan Kundera conceives the creation of the characters in his novel. In particular, the discussion is to extract the characters in his celebrated novel The Unbearable Lightness of Being (henceforth ULB) and try to understand the concept of existential code in his characters. This step will enrich our understanding on how the mimesis theory has specific articulation in Kundera's writing process, especially the way he develops the characters of his novels.

Additionally, this part of the article is also to underline Kundera's claim on the difference between novel and philosophy. In his book The Art of the Novel, Kundera notes that philosophy develops its thought in abstract realm, while novel always builds its characters from a concrete situation. He says the following: "I find the word 'philosophical' inappropriate. Philosophy develops its thought in an abstract realm, without characters, without situations [...] the reflection introduces directly, from the very first line of the novel, the fundamental situation of a characterTomas; it sets out his problem: the lightness in a world where there is no eternal return." (Kundera, 1988, p. 29). In the interview about the publication of The Unbearable Lightness of Being with France Culture radio in France, Kundera further mentions that he is not a philosopher; he does not create a philosophical system, but he inserts philosophical interrogation in his novel. (https://www.franceculture.fr/litterature/milan-kundera-souffre-par-linsignifiance-de-toutce-que-nous-vivons). Mentioned must be made here that Kundera's philosophical interrogation is useful here despite the non-exhaustive exposition of the richness of this novel, as shown by numerous studies on Kundera that explore the richness of his œuvres (e.g. Mai, 2014; Češka \& Thirouin, 2011; Vibert, 2014).

Now, to begin our exploration in Kunderian world of developing characters, it is interesting to note that one feature of Kunderian novels is the apparition of the author in his novels. For example, Kundera comes across as giving his personal comments about the characters he creates. In his study on the works of Kundera, François Ricard states the significance of the presence of the author in the novel. Ricard divides the Kunderian into several cycles. He notes that The Unbearable Lightness of Being belongs to the second cycle of Kunderian novels, written in the span about ten years, together with The Book of Laughter and Forgetting finished in 1978, and Immortality in 1988. He says: "[The author] is another feature of the Kunderian novel, what I would call the non-obliteration of the author and his assertion in the very midst of the narration through a clearly identified voice and thought that fear neither to indicate their presence nor to declare their position concerning the depicted universe, yet not removing its autonomy or its own reality." (Ricard, 2003, pp. 123-124). Here we see that the The Unbearable Lightness of Being is contemporary to Ricœur's Time and Narrative 1.

We shall now examine Kundera's assertion as the author in The Unbearable Lightness of Being. Kundera firstly says the following in this novel: "It would be senseless for the author to try to convince the reader that his characters once actually lived. They were not born of a mother's womb; they were born of a stimulating phrase or two or from a basic situation..." (ULB, p. 39). Next, he repeats this idea again: "As I have pointed out before, characters are not born like 
people, of woman; they are born of a situation, a sentence, a metaphor containing in a nutshell a basic human possibility that the author thinks no one else has discovered or said something essential about." (ULB, p. 221). At this point, where Kundera states that his characters were born from a metaphor or from fictional situation in his novel to manifest and to open human possibilities, we will discover the rapprochement between Kunderian way of creating characters and the Ricœurian concept of metaphor and referential status of a narrative text as explained in the previous section.

Furthermore, in the case of Kundera, he even adds clearly that these new possibility surpasses what he himself has undergone. Indeed, the way his characters is going beyond his own reality as their author, is what he himself is most attracted, as he says: "The characters in my novels are my own unrealized possibilities...Each one has crossed a border that I myself have circumvented. It is that crossed border... which attracts me most." (ULB, 221). We can still give another comment for this citation. By stating the correlation between his life as an author and the characters in his novel, we find another accentuation of what Ricœur states that the narrative configuration (mimesis ${ }_{2}$ ) has its sources in the ordinary life pre-narrative (prefiguration phase or mimesis ${ }_{1}$ ). We can imagine that his life in the socio-political context of Czech of the day, for example is that of the totalitarian regime. That context gave him abundant sources for The Unbearable Lightness of Being.

Behind this effort to manifest the different new possibilities in his characters, it is clear that in The Art of the Novel, Kundera gives us the key to enjoy, to explore, to understand, and to benefit from the characters in his novels by the act of reading. It is what Kundera calls existential code. The existential code of his characters as imaginary being is built by certain key words. He said in this book, "To apprehend the self in my novels means to grasp the essence of its existential problem. To grasp its existential code. As I was writing The Unbearable Lightness of Being, I realized that the code of this or that character is made up of certain key words...Each of these words has a different meaning in the other person's existential code" (Kundera, 1988, p. 142). This so-called existential code is the main theme shown by his characters. For Kundera, the novel is a great prose where he can explore different existential problems: lightness-weight for Tomas, body and soul for Tereza, for example.

Again in his interview with France Culture radio, he mentioned one existential question: the lightness and the weight in The Unbearable Lightness of Being, and he asked whether we are suffered from the insignificance of the life or from the dramatic burden of our life (https://www.franceculture.fr/litterature/milankundera-souffre-par-linsignifiance-de-tout-ce-que-nous-vivons). This question, as all fundamental questions about existence, cannot be resolved. Thus, it is clear here that his novel does not offer solutions to different existential codes explored in the novel. It is instead a thorough exploration of different existential codes, different existential questions, and different new possibilities from this point of departure. Considering this argument, I think that these new possibilities become a way to work on such existential question, rather than a direct solution to the problem. The existential problems are always there, but there is some new ways to work on it. Further, it is therefore the task of the readers to take some new directions in their act of reading as proposed by mimesis 3 . 
Now, more question surface as to whether the existential codes and the new possibilities opened by the characters are limited in some sense by the presence of the author, even in the midst of the novel. In other words, is not the presence of the author a sort of omnipresent which in the narrative level can be regarded as a method that puts the limit of the new possibilities of the characters? In the end, does this omniscient presence of the author limit the freedom of the characters? If so, then what is the aim of stressing that the characters stimulate these new possibilities? Is it not that attempt is so paradoxical with the presence of the author himself in this novel?

The analyses of François Ricard cited above give immediate answer as well as more series of questions. He states clearly that the presence of the author does not remove the autonomy of the universe of the novel. However, does Kundera himself manifest this aspect in his novel? How can Kundera reconcile his presence and the freedom of his characters? To answer to this question, it is interesting to note that in many occasions, Kundera limits himself as being ignorant to what his characters are doing or thinking.

Kundera shows his difficulty to understand what Tereza thinks when she compares her photos on the Russian invasion to the nude photos in the beach: "...even I find it difficult to explain what she had in mind when she compared a nude beach to the Russian invasion." (ULB, 69). In another comment, Kundera will only give his opinion or his speculation about the reason why Franz asks Sabina to go to Palermo for their love affair and not in Geneva as desired by Sabina. Kundera says this: "The only explanation I can suggest is that for Franz, love was not an extension of public life but its antithesis." (ULB, 83). Another example of this can be found when he asks whether there is a kind of es muss sein in Tomas' life or not. He shows only his opinion about that, saying "In my opinion, it did have one. But it was not love, it was his profession." (ULB, 193). Kundera's technique of characterization limits himself; he does not manifest the omniscience feature of a narrator. As Hana Pichova puts it, the characters may be his creation, but they have their own universe. This universe, even the author himself does not have the power to intrude (1992, p. 222).

In the narrative level, by using such technique, Kundera brilliantly avoids the danger of the omniscient presence of the author that could be interpreted paradoxically as an obstacle to the freedom and thus the new possibilities brought by the characters; the new possibilities sought by the very author. In so doing, Kundera successfully restrains himself from the intrusion to the psychological conditions of his characters. As such, he lets his characters decide and free themselves.

Refusal to enter into the depth of the psychological realm of his characters, gives the chance to the characters to build their own possibilities in maximum. We may assume here that this is a creative configuration from what Kundera perceived from the ambience of socio-politically totalitarian Czech he found in his daily context. We can grasp this, by what he points out in The Art of Novel, when asked why there is a complete absence of interior monologue in his novel, Kundera clearly says that he cannot use the espionage method for it $(1988$, p. 29). He wanted to show human freedom, the new possibilities to live better, amidst the totalitarian regime that he sought to confront. 


\section{Conclusion}

This article has elucidated the mimesis theory by Ricœur and the existential code in the Kunderian novels. It has demonstrated why people must continue writing novels and why people must also continue reading it. Novel, thanks to its creative imagination in the emplotment process, imitates creatively the world of human actions. Its configuration opens some existential questions of human being and proposes some new possibilities to live better in the world. The decisive moment of refiguring life happens when someone reads the novel and makes his own appropriation about different propositions to re-work those existential questions. The novel and the appropriation we made upon it will send us back to the current, now as a person refigured by the novel.

This article has also shown that man tries unceasingly to understand both him and the world he lives in along his journey between his birth and his death. He is always in search of meaning of his temporal experiences. Thanks to the mediation of what he has read, this new person, the refigured one, then, is the person who understands better both himself and the world he lives in. He will be sent back to the place he left before his reading, but now with a better understanding, with new possibilities and meanings as beautifully indicated by T.S. Eliot in his poem "The Little Gidding" thus: We shall not cease from exploration. And the end of all our exploration will be to arrive where we started and know the place for the first time.

\section{References}

Amalric, J-L. (2013). Paul Ricour, l'imagination vive. Une genèse de la philosophie Ricœurienne de l'imagination, Hermann éditeurs, coll. Hermann Philosophie, n.p.

Češka, J. \& Thirouin, M-O. (2011). Le roman comme déploiement symbolique du rêve: La thématique du rêve dans l'oeuvre de Milan Kundera. Revue des études slaves, 82(3), 457-478. JSTOR access 22/02/2019.

D'allonnes, M. R. (March 2014). La vie refigurée: Les implications éthiques du récit. Archives de Philosophie, 74(4), 599-610. JSTOR access 20/10/2015.

Dastur, F. (Octobre-Décembre 2011), La critique ricœurienne de la conception de la temporalité dans etre et temps de heidegger. Archives de Philosophie, 74(4), 565-580. JSTOR access 22/02/2019.

Ferguson, A. (November 2014). R. A. Lafferty's escape from Flatland; or, how to build a world in three easy steps. Science Fiction Studies, 41(3), 543-561. SFTH Inc. JSTOR access: 22/02/2019.

Geniusas, S. (Summer 2015). Between phenomenology and hermeneutics: Paul Ricœur's philosophy of imagination. Human Studies 38(2), 223-241. JSTOR accessed 23/02/2019.

Grondin, J. (2013). Paul Ricœur. (2013). Paris : PUF, Coll. «Que sais-je ». https://www.franceculture.fr/litterature/milan-kundera-souffre-parlinsignifiance-de-tout-ce-que-nous-vivons. Acces 14/02/2019.

Kundera, M. (1984). The unbearable lightness of being. New York: Perennial Classics.

Kundera, M. (1988). The art of the novel. New York: Perennial Library. 
Lior, L. L. (March 2014). Sartre and Ricœur on productive imagination. The Southern Journal of Philosophy, 52(1). JSTOR accessed 23/02/2019.

Mai, J. (Spring 2014). Humanity's "True Moral Test": Shame, Idyll, and Animal Vulnerability In Milan Kundera's "The Unbearable Lightness of Being". Studies in the Novel, 46(1), 100-116. JSTOR access 23/02/2019.

Pellauer, D. (2013). Ricœur and white on the historical imagination. Archivio di Filosofia, 81, (1/2), Attraverso La Crisi E Il Conflitto. Pensare Altrimenti Con Paul Ricœur 261-270. JSTOR accessed 23/02/2019.

Pichova, H. (Summer 1992). The narrator in Milan Kundera's the unbearable lightness of being. Slavic and East European Journal, 36(3).

Prammer, F. (2013). Poetic discourse: A resource for thinking and acting differently in a time of crisis? Ricœur's perspectives on poetry's relation to reality. Archivio di Filosofia, 81(1/2), 223-232. JSTOR, access 21/02/2019.

Ricard, F. (2003). Agnes's final afternoon: An essay on the work of Milan Kundera. London: Faber and Faber.

Ricœur, P. (1984). Time and narrative. Volume 1. The University of Chicago Press.

Ricœur, P. (1986). Du Texte à l'action. Essais d'herméneutique II. Editions du Seuil (Points). Paris.

Ricœur, P. (1988). Time and narrative. Volume 3, The University of Chicago Press.

Ricœur, P. (1995). Réflexion faite. Autobiographie intellectuelle. Paris: éditions Esprit.

Ricœur, P. (2013). Cinq études herméneutiques, Labor et Fides, Genève.

Tengelyi, L. (Octobre-Décembre 2011). Refiguration de l'expérience temporelle selon Ricœur" in Archives de Philosophie, 74(4), 611-628. JSTOR access 22/02/2019.

Vibert, B. (Octobre - Décembre 2014). L'entre-Deux De "Risibles Amours" Et Du "Livre Du Rire Et De L'oubli" De Milan Kundera : Recueils De Nouvelles Ou Romans? Revue d'Histoire littéraire de la France, 114e Année, 4, 911-932, Presses Universitaires de France, 2014. JSTOR access 22/02/2019.

Young, T. (Winter 2014). Brooklyn as the "untold story" of "Eveline": Reading Joyce and Tóibín with Ricœur. Journal of Modern Literature, 37(2), 123-140. JSTOR access 21/02/2019. 